\title{
Entrevista: Paulo Arantes
}

Entrevistadores:

Alexandre Duarte Bassani

Elizete Waughan da Silva

Gabriela Sanches Ribeiro

Israel Rossi Milhomem

Larissa de Carvalho Nascimento

Leandro Lopes Zuffo

Luana da Silva Spósito

Mariana Faciulli

Roberta Baessa Estimado

Thiago Kenji Nakamura Garcia

Thomáz Fortunato 
Humanidades em Diálogo: Nós, da Revista Humanidades, temos o prazer de receber o professor Paulo Arantes. O senhor pode se apresentar, por favor?

Paulo Arantes: Eu me formei em I967, na Faculdade de Filosofia, que naquela época se chamava Faculdade de Filosofia, Giências e Letras. Entrei em I965 e me formei em três anos. Fiz um curso muito rápido, porque eu já havia cursado um ano de Física e Matemática e, então, pude pular algumas disciplinas optativas, de modo que me formei em I967. Logo em seguida, em I968, comecei a dar aula.

Há duas coisas interessantes a respeito dessas breves informações. Primeiro, o fato de ter feito o curso em três anos, quando era em quatro anos que normalmente se fazia, ou um pouco mais. E, em segundo lugar, ter começado a dar aula cedo. Naquela época, não havia concurso e eu fui convidado a dar aula - fui cooptado. Esse é um dado interessante e importante. Não fui eu o único a ser introduzido na carreira desse modo. Isso acontecia com todos os jovens professores. O sistema ainda era de Cátedra, com dois catedráticos, no caso, o Cruz Costa e Lívio Teixeira. Não existia Departamento de Filosofia. Havia uma ficção acadêmica do que hoje é o Departamento de Filosofia pela associação dessas duas cadeiras. Os catedráticos tinham prerrogativas de monarquia absoluta. E, nesse sistema de cátedra que ainda havia naquele momento, eles podiam perfeitamente nomear os seus assistentes. Então não havia concurso. Era quem eles escolhessem para serem seus assistentes. Na verdade, não fui escolhido pelos catedráticos, mas, assim como meus colegas da mesma geração, por seus assistentes. Esses jovens assistentes, que já operavam como departamento, eram o Giannotti, o Porchat, o Bento Prado e, em menor proporção na escala do mando, o Ruy Fausto. Eram basicamente esses quatro ou três que puxavam os cordões do Departamento, uma vez que os professores catedráticos haviam abdicado de seu mando acadêmico. Por uma espécie de esclarecimento ou lucidez, então, eles formaram, precocemente, um departamento, antes da reforma universitária, que seria feita pela ditadura e daria um impulso novo à nossa academia. Quando havia reunião de departamento, às vezes eles apareciam, às vezes não. A gestão era inteiramente delegada para esse pequeno grupo que cooptava os seus melhores alunos.

O que justificava esse tipo de escolha, digamos, era um raciocínio ilustrado e, ao mesmo tempo, que poderia ser considerado, no limite, mafioso: é necessário que formemos os professores que depois iremos contratar. Do contrário, se isso não fosse feito, se houvesse, por exemplo um concurso, ou algo do gênero, o Departamento de Filosofia - portanto, a excelência acadêmica da filosofia uspiana que nós queremos formar e que já está se formando 
- seria extirpado pela raiz. Isso porque, se houver um concurso, nenhum dos nossos bons alunos, que nós formamos com tanto esmero durante quatro anos, terá a menor chance. Qualquer professor, qualquer veterano com currículo, certamente ganharia. Desse modo não teríamos chances de formar um departamento à nossa imagem e semelhança, isto é, com aqueles que formamos. Então, nesse momento, o sistema arcaico de cátedra nos favoreceu. Se não fosse isso, não haveria a FFLCH como existe hoje.

Então, a escolha dos futuros professores assistentes se dava desde o primeiro ou segundo ano. Todo mundo lia os trabalhos uns dos outros. Quando havia um aluno que se destacava, passava-se a dissertação aos colegas, que davam palpites e comentavam: "esse cara é bom mesmo". Porém, esse modelo tinha seu lado perverso, obviamente. Perdurando esse sistema, nós perpetuaríamos a ideia de que "nós somos os melhores, nós cooptamos os melhores, nós integramos os melhores, é nós com nós. Nós somos o alto nível em filosofia”. Portanto, a tendência foi tornar-se uma espécie de cooperativa do elogio mútuo, do reforço mútuo. Fechávamo-nos como uma casta. Sendo cooptado, já no terceiro ano sabia que seria contratado. Três ou quatro professores já haviam me dito "você vai ser contratado, prepare-se para assinar os papéis em tempo". Outro aspecto disso era que essa contratação precoce era muito desagradável, porque, da noite para o dia, passei a ser professor dos meus colegas, algo incômodo, que lembro de não ter gostado. A partir de I968, comecei a dar aula para muitos dos meus colegas de classe, e era muito desastrado, muito desajeitado, muito encabulado, justamente por causa disso. Me questionava "quem sou eu para dar aula?". Fui contratado dessa maneira em I968 e dei aula normalmente no Departamento de Filosofia até 1998, quando me aposentei, depois de trinta anos de magistério, como era a regra naquele tempo.

Outro privilégio daquela época, e que hoje ainda é possível, foi pular o mestrado. Por outro lado, só havia a exigência de fazer o doutorado, condição sine qua non para continuar sendo assistente na cátedra. No caso, a minha cátedra era a do Cruz Costa, que havia assinado os meus papéis, endossado pelo Giannotti. Era a cátedra de filosofia geral. Nessa situação, pude fazer o doutorado rapidamente. Entretanto, não havia pós-graduação no nosso curso. Então, eu fui escalado, ou autorizado, a fazer diretamente o meu doutorado na França. Embora seja uma tese difundida, o Departamento não foi fundado por franceses. Isso é um mito. Ele foi fundado na própria USP. Mas havia um convênio com o governo francês, com o Ministério de Relações Exteriores da França - não era o de educação. Desse modo, havia dois postos franceses no Departamento (vamos chamar de Departamento) de Filosofia. Esses dois postos franceses faziam parte de um programa diplomático do governo francês e 
foram mantidos até meados dos anos oitenta, salvo engano. Passávamos uma temporada - um ano, um ano e meio, dois - na França, em princípio para fazer um curso suplementar ou, enfim, estudar sob a orientação de alguns dos mestres franceses, como o Goldschmidt ou o Granger. Passado esse tempo, voltávamos ao Brasil e fazíamos o doutorado aqui. Eu fui o primeiro a realizar o doutorado completamente na França, por circunstâncias de mera sorte. De modo que fiquei quase quatro anos lá. Nesse período, realizei o doutorado lá e voltei ao Brasil com a tese defendida em junho de 1973 .

Um segundo ponto interessante, como peculiaridade de época, é um fato relacionado com a estrutura geral da universidade, que vocês obviamente nunca mais irão conhecer. Foi uma espécie de idade de ouro... Interregno que, no meu caso, tornou possível a vida mental, inclusive do ponto de vista emocional, porque a pressão era "pequena" (havia outros tipos de pressão, mas depois a gente pode conversar sobre essas coisas). A única exigência que a Universidade de São Paulo fazia (quando eu digo Universidade de São Paulo, me refiro à FFLCH. Faculdade de Direito, Poli, Medicina são, digamos, organizações coercitivas perversas diferentes da nossa) era o doutorado. Uma vez feito o seu doutorado, você estava livre de qualquer tipo - para usar a linguagem corrente hoje - de cobrança. Não havia ainda a cobrança de produtividade tipo linha de montagem de hoje. Era simplesmente impensável. Não havia, no nosso caso, nem revistas de filosofia para publicar. Assim, publicar onde? O quê? A partir de um certo momento, no final dos anos 1960 e início dos anos 1970, os jornais começaram a aceitar esses artigos. Em I969 apareceu nossa primeira revista de filosofia, a Discurso. Logo, fazíamos o doutorado e ficávamos livres. Não havia nenhum tipo de obrigação acadêmica, a não ser dar aula. Depois, com a pós-graduação, tínhamos também que orientar tese. E pronto! Nessa situação, podia-se respirar. Não existia uma máquina de produção de papers, o que permitia um comprometimento maior na preparação de boas aulas. Preparar aula, imaginem só! Alguém cuja única obrigação em uma semana era preparar uma boa aula expositiva ou um seminário de cinquenta minutos. De certa forma, poderia dizer que a minha carreira se encerrou com o doutorado. $\mathrm{O}$ salário era suficiente, então era possível ter uma vida saudável do ponto de vista intelectual e emocional sendo apenas um doutor e tendo como único compromisso preparar e dar o seu curso.

Humanidades em Diálogo: Por diferentes razões, essa questão da produtividade é discutida atualmente no Departamento. A título de exemplo, as iniciações científicas, que passam a alguns professores e alunos uma im- 
pressão de especialização precoce. Esse produtivismo associado a uma especialização precoce pode propiciar um isolamento do aluno de filosofia? Em Um Departamento Francês em Ultramar, fica claro como o método de leitura estrutural dos textos filosóficos foi importante no Departamento de Filosofia da USP, sobretudo na época da ditadura militar. Gostaríamos de saber se esse método de leitura ainda poderia colaborar com a formação de um pensamento crítico, tendo em vista que o curso de filosofia é majoritariamente de história da filosofia. Isso nos interessa, pois temos um curso de filosofia muito conceituado, mas que não consegue se articular com o momento histórico. Em sua época na FFLCH já existia essa dificuldade, mas no momento atual, que exige uma transformação importante sobretudo na política, gostaríamos de saber se o senhor tem hipóteses sobre o isolamento da filosofia.

Paulo Arantes: Bom, acredito ter que fazer duas perguntas a vocês para saber o que vocês estão pensando com essa pergunta. Por que o método estrutural foi muito importante durante a ditadura? É a primeira vez que eu ouço isso, e é interessante. E o que que vocês entendem por isolamento da filosofia? Para vocês terem uma ideia, eu estive na primeira reunião de fundação da ANPOF (Associação Nacional de Pós-Graduação em Filosofia). A fundação foi em 1984, em Diamantina. Havia cem pessoas, se tanto, do Brasil inteiro para fazer uma associação nacional de pós-graduação em filosofia. Eu fui nesse primeiro e depois só voltei a um congresso da ANPOF tempos depois (30 anos!), em 20I4, quando me convidaram para falar sobre Junho de 2013. Foi em Campos de Jordão e acho que tinha de três a cinco mil pessoas. Essas três mil pessoas foram selecionadas em um universo muito grande de papers. Então, quando vocês falam em isolamento, eu me pergunto: é claro que o país tem duzentos milhões de habitantes, mas o que significa esse isolamento, com um congresso de pessoas especializadas em filosofia que reúne essa população assombrosa? Isso não existe em lugar nenhum do mundo. Então o que é isolamento? E, em segundo lugar, por que o método estrutural funcionou como uma trincheira ou foi importante na ditadura?

Humanidades em DiÁlOgo: Não acreditamos que o método estrutural tenha sido propriamente uma trincheira, mas acreditamos que foi importante para a sobrevivência do curso. Diante da aposentadoria forçada de certos professores e de outras formas de repressão no espaço acadêmico, esse método parece ter contribuído para que a filosofia não fosse uma ameaça direta. $O$ pensamento crítico na época da ditadura não era algo 
interessante, então parece que o método estrutural e o ponto de vista histórico da filosofia não abrem portas para o pensamento crítico...

Paulo Arantes: Olha, eu nunca... Eu já disse muitas coisas altamente favoráveis a esse método, e também já disse horrores quanto a ele, mas nunca me ocorreu um argumento como esse. Incrível.

Humanidades em Diálogo: Esse argumento, na verdade, é porque vemos que os estudantes de filosofia aqui da USP e de várias universidades não têm uma atuação política. Esses alunos não se colocam diante dos problemas que tangem até mesmo à própria universidade. Assim, somos [a entrevistadora era do curso de filosofia] considerados como espectros no prédio por companheiros das ciências sociais. Sabem que estamos lá, mas nunca nos veem.

Paulo Arantes: Eu nunca vi um argumento desse. É curioso. Se eu compreendi bem, é mais ou menos o seguinte: até o AI-5, como se sabe, a vida intelectual foi preservada, enquanto a ditadura bateu forte nos meios populares, sindicatos, ligas camponesas e subversivos de maneira geral. A vida intelectual universitária e cultural foi relativamente preservada e isolada. Isso é uma tese clássica, na interpretação da vida cultural nos primeiros anos da ditadura até o AI-5, mais ou menos admitida. Bom, e vocês propõem o seguinte raciocínio: o método estrutural, de certa maneira, é politicamente anódino e inócuo - low profile político. Não há, ao contrário do que seria em departamentos como os de Ciências Sociais, qualquer coisa que tenha a ver com a espécie de consequência social esperada envolvendo gente de esquerda. A Filosofia, por outro lado, seria mais etérea, prospera na atmosfera rarefeita de uma estufa, e por lá fica. Isso em razão, talvez, desse método que provoca uma espécie de ensimesmamento dentro do texto e não oferece nenhum pretexto para ser politicamente reprimido. Nunca tinha ouvido falar isso.

Portanto, esse método foi muito útil porque não chamou a atenção da ditadura. Logo, tinham-se aqueles sujeitos alienados, no sentido banal do termo, descascando textos clássicos e que, consequentemente, não incomodavam ninguém. Enfim, não "fazia coceira na ditadura", ao contrário de gente de ciências sociais, que estudava Marx ou assemelhados e que poderia se radicalizar - embora no nosso Departamento estudasse-se Marx, era como mais um clássico entre outros.

Deu-se, no entanto, um notável curto-circuito. Em I968, entre maio e junho, a faculdade foi ocupada contra a ditadura e os descalabros do Ministé- 
rio da Educação. Exigíamos uma reforma universitária e o governo paritário da Universidade. No nosso departamento, elegeu-se uma comissão paritária de estudantes e de professores para dirigi-lo. A radicalização foi geral. Daquela ocupação da faculdade entre maio e setembro de I968 saíram muitos que depois foram à clandestinidade e mesmo à luta armada. De modo que, se houve radicalização na USP, foi naquele momento, que se apresentou como um embrião do que viria pela frente. Era uma tendência que já vinha de longe, mas naquele instante tivemos esse auge, que permitiu que, depois, nossos alunos partissem para outros enfrentamentos. No momento em que se instaurava o processo de instalação da paritária no Departamento, os grupos estudantis radicais tinham ideias de se reformar o ensino de Filosofia associado com a reforma da Universidade de maneira geral e com a democratização do poder acadêmico. Imagine uma assembleia de ocupação do curso de filosofia, em meio à ditadura militar, num departamento com não mais de duzentas, trezentas pessoas entre professores e alunos. Os estudantes que eram maoístas, leninistas, guevaristas, ala vermelha disso, ala vermelha daquilo... O que eles exigiam? Eles não queriam mais tantos cursos de Bergson e Aristóteles. Isso já não os interessava mais como nos primeiros tempos de iniciação mais ou menos inocente à cultura filosófica, mas agora pediam, de acordo com a exigência radical do momento, cursos sobre Lênin, Mao Tsé-Tung, Che Guevara e de todo o espectro radical. Porém, cursos rigorosos, porque "nós não barateamos nada, nem aceitamos o baixo nível, nós queremos cursos radicais de esquerda, mas rigorosos segundo o método estrutural da escola francesa”. Então, veja: não só não havia incompatibilidade intrínseca, como também não era um escudo para desviar a atenção do aparato repressivo e vigilante da ditadura. Bom, isolamento em que sentido?

Humanidades em Diálogo: Justamente na atuação política. Em geral, pouquíssimos professores se posicionam no Departamento, no caso. E os próprios estudantes não se articulam politicamente...

Paulo Arantes: Bom, hoje eu não posso falar, eu não conheço, e nem me caberia falar.

Humanidades em Diálogo: A primeira pergunta, na verdade, era se o método estrutural ainda teria um potencial a oferecer, como ele ofereceu no caso do Seminário Marx.

Paulo Arantes: Olha, eu acho que o Seminário Marx foi também uma coisa bem conjuntural, como explicado no ensaio do Roberto Schwarz. Eu também 
toco nesse assunto no livro. Esse é um argumento que está no livro e é uma maneira pela qual os professores justificavam ou faziam um elogio do que é, como se dizia naquela época, o estruturalismo historiográfico francês Goldschmidt, Gueroult e outros. Mesmo antes de Goldschmidt e Gueroult, era essa a maneira pela qual se entendia filosofia, pois o estudo de filosofia na universidade francesa foi transplantado tal e qual para o Brasil. Esse transplante, ao invés de ser alguma coisa que te alienasse da realidade, pelo contrário: funcionou para desenvolver uma espécie de espírito crítico - inclusive no sentido filológico - de se criticar um texto. Não no sentido de crítica-rejeição, mas crítica-exame, porque funcionava como uma espécie de antídoto para um rebaixamento eventual que se daria pela contaminação com o meio ambiente cultural e social, mais ou menos medíocre, de maneira que fazia com que você se isolasse, e esse isolamento, num certo momento, foi positivo. Isso porque, ainda que se tratasse de um isolamento seguramente de jardim de inverno, ele conseguia se destacar da mediocridade do ambiente: mediocridade não só dos nossos bacharéis de sempre, mas também do autodidatismo, dos nossos pretensos filósofos ou sociólogos, e mesmo de gente de esquerda. Então, isso fez com que houvesse uma espécie de enclausuramento, pois nesse isolamento você dava as costas para um processo social complexo como era o nosso, o que, no entanto, acabava por possibilitar essa planta de estufa a crescer numa atmosfera propícia ao espírito crítico, que, por sua vez, repousava sob uma espécie de aposta no processo de esclarecimento social através da cultura organizada na forma de seu ensino superior.

É como se o progresso das luzes, o progresso do conhecimento, o progresso da inteligência, fizesse com que se criasse e forjasse uma personalidade intelectual e moral que fosse incompatível com a iniquidade de uma ordem social horrorosa como a do Brasil. No meu caso, a ficha demorou muito tempo a cair, pois isso nunca foi formulado dessa maneira. Mas tal crença foi explicitada em alguns textos que nem eram puramente filosóficos, mas que diziam o seguinte: nós nos esforçamos muito para entender um filósofo clássico - estávamos falando de Descartes, mas poderia ser Kant, poderia ser um filósofo abstruso tipo Fichte. Enfim, algum dos clássicos da filosofia ocidental europeia, que é a nossa tradição. O fato de a gente quebrar a cabeça pra entender o que esses filósofos disseram e, sobretudo, argumentavam; como é que eles pensavam; não para aderir ou recusar a doutrina deles, e sim para entender a maneira deles de pensar, de encadear uma ordem de razões, faria toda a diferença do mundo. Estávamos, portanto, diante de uma máquina pensante tal que provocaria em nós uma espécie de conversão filológica hermenêutica de nossa própria inteligência, uma inteligência que se torna política na exata me- 
dida em que não tolera mais a persistência da iniquidade social, que não casa com a simples ideia de pensar com a própria cabeça. Então, o que é o método estrutural? É o seguinte: façam um esforço para entender o que o filósofo quis exatamente dizer, malgrado ele mesmo. Não a intenção subjetiva do filósofo, do autor, mas daquele texto que ele escreveu e assinou de maneira responsável. Façam o esforço de entender o que aquele texto envolve, como ele funciona para justificar suas teses internas, as quais valem não como teses isoladas, como dogmas, mas como uma estrutura de pensamento.

Para se entender isso, é preciso entender a primeira consequência do exercício desse espírito de exegese crítica, do qual não se tem como escapar, porque ele desarma a opinião dogmática e doutrinária que se possa ter sobre um filósofo. Por exemplo, vindos da esquerda dos anos I950, os alunos chegavam às aulas e enfrentavam um curso sobre Platão. A primeira reação era considerar Platão um filósofo alienado, idealista, ideólogo da escravidão grega etc. $\mathrm{Ou}$, ainda, pensar que a doutrina das ideias é uma coisa estapafúrdia e que não faz mais sentido e, por isso mesmo, foi superada. É nesse aspecto que o método estrutural, por assim dizer, civilizava, pois sugeria irmos com calma, tanto na adesão anacrônica quanto na refutação idem, ou seja, você poderia suspender o seu juízo e, durante um determinado momento, tornar-se um discípulo de Platão. O fato de, durante uma temporada, alguém se tornar discípulo de Platão e suspender todos os seus preconceitos a respeito dele, todas as ideias pré-concebidas, e procurar entender o que está acontecendo num diálogo platônico, é uma espécie de processo civilizatório e era nisso que se apostava. Assim, "desdogmatizavam-se" os espíritos, "desdoutrinizava-se", "desprovincializava-se" e aguçava-se o entendimento geral das coisas. Por outro lado, esse entendimento era estritamente formal, uma vez que o que importava era a verdade formal de um sistema, se ele era coerente, e não a verdade material. Se ele dizia a verdade sobre o mundo. Assim, não havia como você sair por aí descrevendo o mundo e comparando-o com a filosofia, para ver se encaixava, e concluindo, caso não encaixasse, que o sistema estava errado. É difícil entender isso, e passaram-se muitos anos naquele Departamento sem que essa ficha caísse. Esse método, então, tinha esses dois lados: em certo sentido ele isolava, porque, para funcionar, tinha-se que esvaziar toda a implicação histórica de um texto filosófico; e, como uma segunda dimensão, esse método filosófico só funcionava, ou seja, só rendia tudo o que ele podia render, em textos clássicos. Quanto mais remoto fosse, melhor. Mas, com os filósofos contemporâneos, por exemplo, isso já não funcionava tanto, porque, em uma leitura estrutural em que você isola, em que você se distancia, você corre o risco maior de tornar-se um contemporâneo inócuo e, 
aí sim, despolitiza-se todo o processo de compreensão. Porém, ainda assim, não se elimina uma questão de simples bom senso, que é entender o que o autor diz, pura e simplesmente, sendo o autor Platão, Hegel ou Descartes... Então, bom, eu gostei desse negócio da ditadura [risos]: $\mathrm{O}$ método estrutural nos preservou da repressão... eu vou guardar essa! Vou usar alguma vez.

Humanidades em DiÁlogo: O PET é um programa baseado em pesquisa, ensino e extensão. E nós aqui da Comissão priorizamos muito a extensão, porque ela possibilita a troca entre sociedade e universidade e colabora com o acesso à universidade pública de grupos que não o teriam normalmente. O curso de Filosofia teve, no seu início, uma formação quase que exclusivamente de elite e, ainda hoje, nota-se que a inclusão de alunos não pertencentes à elite é muito tímida. Gostaríamos que você comentasse as consequências a longo prazo da manutenção de um público predominantemente de elite no curso de Filosofia, tanto para a sociedade como para a Filosofia.

Paulo Arantes: A elite nunca esteve na FFLCH. Ela vai para as faculdades de Direito, Medicina, para a Poli, ou seja, para as faculdades de ponta da Universidade de São Paulo. A FFLCH, desde o início, sempre foi uma faculdade de classe média e, por vezes, classe média baixa. A ideia de que foi uma faculdade de elite vem de uma ilusão retrospectiva pelo fato de ter sido fundada por europeus. Na época da fundação da Faculdade de Filosofia, foi recrutado um certo número de professores franceses e, aí sim, recrutou-se um corpo docente talhado para a oligarquia paulista. Essa oligarquia pensou a fundação da Universidade de São Paulo dispondo do refinamento de um curso europeu que lhe serviria de sobremesa. Portanto, havia uma curiosidade diletante em volta disso, mas, na verdade, os professores e os alunos que foram para lá eram classe média. Na realidade, o Brasil afundou tanto que a classe média que está enterrada na FFLGH parece elite, mas não é. A Faculdade de Filosofia foi formada como um projeto da elite. A oligarquia paulista que estava se opondo ao varguismo de um modo geral queria uma faculdade que cultivasse a ciência por ela mesma, e não no sentido instrumental, profissional, liberal, como nas faculdades clássicas, que serviam para formar a classe dirigente do país. Além disso, essa elite suspirava por todos os melhoramentos da vida moderna, como uma faculdade em que se cultiva o saber pelo saber e que forma professores de literatura, de línguas estrangeiras, matemáticos, físicos, químicos, biólogos, professores de filosofia, sociólogos, antropólogos etc. Tudo isso sem uma finalidade instrumental. Era um luxo moderno que se ostentava contra a gros- 
seria do varguismo. De maneira geral, para mostrar que a elite de São Paulo era mais cultivada e mais avançada, buscou-se por professores e pesquisadores à altura dessas ambições de elegância intelectual. Nesse sentido, foi uma concepção de elite mesmo pela qual a nata da oligarquia brasileira expressava o seu desprezo pelos novos donos da política brasileira. Mas o que aconteceu? Eles não calcularam que a faculdade precisava ter alunos. Eles imaginavam importar um carregamento de filósofos, sociólogos, historiadores franceses e, depois de os desembarcar, alojá-los - boa parte era paga pelo governo francês - e pronto. Haveria conferências brilhantes, como se assistia em Paris. Só que se esqueceram desse detalhe: tem que ter aluno. Todas as histórias da USP contam isso. Está tudo documentado. Isso foi em 1934, mas era a oligarquia local que mandava, em pleno regime Vargas, com o Paulo Prado, o Fernando de Azevedo, a família Mesquita... O que acontece? Abrem-se as matrículas e não tem aluno para se inscrever. Como é que a gente faz? Não tem aluno! Acho que foi o Fernando Azevedo quem teve uma ideia genial e pediu para o governador fazer o seguinte: nós vamos comissionar professores da rede estadual de ensino para que façam o curso. Vejam só. Quem eram os professores da rede estadual do ensino secundário no estado de São Paulo? A classe média! E média bem "mediazinha". Imaginem só. Bom, então você pega professores do curso secundário de São Paulo (que era bom; havia ginásios extraordinários; eu me formei no ginásio do estado, lá em Santos) e os comissiona para ficarem quatro anos licenciados - quatro anos pagos, uma bolsa, e liberados do ensino, convivendo com o que havia de melhor na cultura mundial, num certo sentido. É claro que não veio o primeiro time francês, nem nada, mas os que estavam começando a carreira na França, o que era uma coisa formidável. Então, quem convivia com isso durante quatro anos era a classe média mesmo! Era a classe média que daria futuramente professores do ensino secundário. Não havia curso superior de sociologia ou filosofia. Você iria ensinar onde? Só poderia ser no secundário; I\% iria ser recrutado pela própria faculdade, como começou a acontecer a partir dos anos 1930 e nos anos I940. Então era tudo, menos de elite. E, como diz Antônio Candido - e ele foi um dos primeiros a lançar a ideia e começar a explicar o que de fato ocorria -, começou a formar-se um pensamento, uma mentalidade radical de classe média. Não tinha nada a ver com elite! Tanto é que os patronos disso, a própria família Mesquita e toda a oligarquia política e econômica, hesita e se perde em reticências: "Opa, alto lá! Não foi isso que nós encomendamos". Aí começa esse jogo ambivalente entre a USP (e sempre quando falo USP é a FFLCH) e os poderes constituídos no jornal Estado de São Paulo, que é o seguinte: "é a nossa faculdade, nós a inventamos, e no entanto só tem gente de esquerda". E, mais 
adiante, com a ditadura: "nós, por assim dizer, começamos a ser 'massificados', começou a entrar muita gente sem eira nem beira". Começaram a escassear os filhos e os herdeiros falidos das famílias tradicionais paulistas, que tinham sido elite há duas ou três gerações atrás e não eram mais. Então, há toda uma mitologia a respeito disso. E, hoje, a Faculdade não tem nada a ver com elite. Aqui é o "fundo do tacho", e é o "fundo do tacho" que é uma parte, digamos, amorfa e meio subversiva (e eu espero que cada vez mais subversiva, não sei)! É gente que sabe que está "ralada". Não tem muita chance, salvo nas universidades que abriram por aí no período que se encerrou agora, e olhe lá.

Humanidades em Diálogo: Entraremos agora no $O$ Novo Tempo do Mundo. Em um dos ensaios do livro, chamado "Sale Boulot: uma janela sobre o trabalho sujo da história", você desenvolve, na nossa leitura, o conceito de trabalho sujo, o qual seria fundamental para compreender o êxito do massacre nazista no Holocausto. Em dado momento, você tece breves comentários sobre o papel da polícia, que seria o lugar natural do trabalho sujo, e cuja "greve de zelo" seria o colapso total de todos seus serviços. Em que medida as concepções de "trabalho sujo" e "zelo", com o excesso que lhes é intrínseco, podem jogar luz sobre o contexto de atuação da polícia militar brasileira? Sobretudo no que diz respeito à morte diária de setores marginalizados.

Paulo Arantes: Bom, primeiramente, ninguém consegue estudar a PM. Ninguém consegue pesquisar a PM, porque a PM não deixa. Mas vamos ao ponto: o trabalho sujo é tão trabalho quanto os outros trabalhos e, portanto, ele é alguma coisa assustadoramente patogênica - produz sofrimento, inclusive - e, no caso da PM, todos os tipos de distúrbios emocionais, transtornos de comportamento e mesmo suicídio, um tema tabu na corporação. Mas você não consegue pesquisar porque você não entra. Eu sei disso porque as pessoas que tentaram fazer esse tipo de pesquisa me contaram. O que é o trabalho policial fora, digamos, do padrão de pesquisa convencional nos estudos sociais? Pra você pesquisar, para ter autorização para entrevistar e acompanhar, você precisa ter o salvo-conduto dos coronéis, e você só tem isso se você passar pro lado deles... Aí acabou a pesquisa. Muita gente tenta fazer, e faz, boa sociologia da polícia militar desde a época da força pública. Mas você não entra no âmago duro do processo. Há um ótimo livro da Martha Higgins. Chama-se Operários da Violência. Ela tentou fazer isso, e é importante. Bom, mas, de qualquer maneira, imagino que não faltem tentativas de interpretação - ou melhor, de imaginação - acerca desse trabalho da polícia enquanto trabalho. 
Então, o que é, nas execuções sumárias que ocorrem nas periferias brasileiras, sobretudo da juventude negra e pobre, o zelo no exercício do ofício policial, de policiamento ostensivo da PM? O que é o zelo? O que eles têm? Eles têm protocolos. Então, recorre-se aos esquemas que eu adotei, que vêm de uma certa psicologia social francesa que eu usei: a psicodinâmica do trabalho, que faz a distinção entre o trabalho prescrito e o trabalho real. E ela começa argumentando pelo caso bizarro da greve do zelo. A greve do zelo significa que você vai cumprir rigorosamente o que manda o protocolo. Por exemplo: onde se faz greve do zelo por excelência, que é operação tartaruga? $\mathrm{Na}$ polícia de fronteira, na alfândega, por exemplo. Para um desembarque no aeroporto, se você cumpre rigorosamente o protocolo, você vai abrir todas as malas rigorosamente, você vai cumprir tudo direitinho, então você vai demorar um dia para liberar um voo. É claro que se você entra no site da PM está lá o protocolo de abordagem, mas você não sabe, em relação a esse protocolo, qual é o real trabalho exercido por um PM que está ali no confronto. Como funciona a cabeça dele? O que ele vê? Quem é o outro, que já está demonizado desde a academia de polícia, pra ele? E como ele vai abordar? O que ele entende por trabalho? Qual é o trabalho dele? Eu não sei, eu precisaria fazer uma sociologia das organizações coercitivas contemporâneas. Como isso se especifica na polícia, nas PMs brasileiras que vêm da ditadura? O que é o trabalho prescrito? O que eles entendem por trabalho? O que é a modificação gerencial na gestão de uma polícia militar, uma polícia militarizada? Uma polícia que segue treinamento militarizado e que é uma força auxiliar das Forças Armadas. A mudança nas Forças Armadas contemporâneas, não só no Brasil, mas no mundo, significa que as forças armadas passaram a ser encaradas como um trabalho! Nunca foram. Elas passaram a ser um trabalho. Tanto é que elas são estritamente profissionais na Europa e nos Estados Unidos, onde contam. Você se alista nos fuzileiros navais americanos como quem entra em uma multinacional, para operar no Iraque, por exemplo. Tem um contrato de trabalho. Nesse contrato, você tem metas a cumprir, você tem um plano de carreira, você tem assistência para a sua família e, depois, tem promessas de emprego, tem várias regalias para voltar porque ninguém quer mais fazer esse trabalho. Então, não é mais serviço militar. É um emprego como outro qualquer. O trabalho de polícia que é feito no Oriente Médio na guerra americana é um trabalho. Bom, sobre isso, nos EUA e na Europa, tem uma biblioteca já escrita sobre essa revolução gerencial que mudou a ideia de forças armadas, de guerra, de combate. Tudo que você possa imaginar. Bom, reduz isso e chegamos à Polícia Militar brasileira. O que significa? Ela funciona como? Ela reprime, 
ela mata, ela estropia, ela esculacha, ela desmoraliza, mas isso é trabalho. Onde é que entra o zelo e a prescrição? Toda vez que tem manifestação (não sei se vocês cheiram bastante lacrimogêneo), vem sempre o bobo alegre de plantão - bobo alegre, não: bobo sinistro - declarar que se cumpriram os protocolos. Mas como cumprir o protocolo? Você calcula os centímetros cúbicos de gás de pimenta pela periculosidade da ofensa... O que é cumprir o protocolo? O que é ter zelo nesse cumprimento? Não mutilar? Não arrebentar? Não estropiar? Nas execuções sumárias, que constam nos BOs como prisão seguida de morte, aquilo foi excesso de zelo? Você abordou como? O que significa fazer a repressão entendida como trabalho? É claro que, para um PM, aquilo é um trabalho. Assim, se fosse adaptar o argumento dessas teorias mencionadas, eu diria o seguinte: não dá para dissociar a repressão do trabalho. Portanto, o problema real quando nós - a esquerda - começamos a criticar, ou falamos da militarização da polícia, ou do comportamento da PM, é que nós esquecemos que o foco é a polícia como trabalho, e não a repressão. Não é que são fascistas, ou cripto-fascistas, que o comando é fascista ou não. O fato é que aquela repressão, aquela violência, aquela brutalidade é encarada como um trabalho, um trabalho como outro qualquer e, portanto, o fato é que o trabalho já está brutalizado. Esse é o problema! Eu vou lá ver como é que funciona isso, mas onde é que eu entro? Bato lá na Academia Tobias de Aguiar pra conversar, o coronel me despacha em meia hora. Aí sim pode ser que a comparação com o Terceiro Reich ou coisas semelhantes proceda, e é só assim que pode funcionar, porque não é fácil para uma pessoa, mesmo que seja um perverso (mas aí já é psicopatia e não interessa), bater e arrebentar com outras pessoas. Você imagina o tipo de violência que uma pessoa deve se autoinfligir para despejar esse tipo de violência extrema em um indivíduo qualquer. Então, ele só pode suportar esse sofrimento. Em última instância, eles se arrebentam, eles se suicidam, eles ficam doentes, eles ficam estressados e isso aumenta a violência, obviamente. Eles só podem encarar e suportar isso se eles encararem aquilo como um trabalho. "Tô fazendo um trabalho, esse trabalho sujo que a sociedade me pede. Pede por quê? Porque eu sou sujo. Eu sou proleta, eu sou negro, eu sou isso, sou aquilo, tô arrebentado, e pedem pra eu fazer isso. Assim, meu zelo é fazer esse trabalho o melhor possível, matar mais. Não porque eu tenha metas pra matar, não é só isso, seria simples demais. Mas eu só posso aguentar essa atividade atroz se eu encaro essa desgraça como um trabalho". Isso é que torna possível essa organização coletiva da violência que é exercida nesse genocídio que está acontecendo no Brasil. Então, você imagina que as pessoas são tocadas por isso. Não porque elas são perversas, autoritárias, 
fascistas. O problema é como está sendo organizado o mercado de trabalho cada vez mais atroz e precário no país e no mundo atualmente. Então você está reprimindo uma população que é descartável. Eles não estão defendendo a propriedade coisa nenhuma. Como a maior parte é fruto de assalto e drogas, significa o quê? Que você pega na mão do fulano que está roubando uma coisa ou está passando uma droga, e é isso. Você só está fazendo isso. Não está defendendo patrimônio de ninguém, nem propriedade, não precisa disso. Esse é o trabalho que você está fazendo. Então você tem que fazer esse trabalho como? Aí começa a ter as ramificações, esse tipo de ofício, mas é trabalho, é encarado como trabalho. O trabalho tem esse lado negro de fazer com que você justifique o horror, o que é a pior coisa que se pode fazer, porque você está cumprindo zelosamente... Você aprende. Daí um certo momento vira, entra na sua rotina. Só que essa rotina, depois, te cobra um preço. Alguns meses depois você desaba, desaba e vai para as clínicas da PM, que ninguém consegue penetrar. Como é que eles fazem terapia? Como é que é? De vez em quando aparece uma ou outra coisinha aí, uns caras que entram lá, porque eles estão arrebentados, e como eles estão arrebentados, eles barbarizam ainda mais. Então não é desmilitarizar. A militarização é apenas uma das "n" rotinas pra você internalizar esse tipo de zelo com o seu trabalho, que é atroz.

Humanidades em Diálogo: A partir do instrumental teórico que você utiliza em $O$ Novo Tempo do Mundo, você acha que as manifestações posteriores a Junho de 20I3, contra o PT e contra todos os corruptos, se encaixam no modelo de "uma paradoxal insurgência dentro da ordem"? A questão da repressão e do Estado de exceção permitem estabelecer uma correlação entre as manifestações de Junho de 20I3, os protestos subsequentes e o processo de impeachment? A partir do diagnóstico do Novo Tempo do Mundo, quais seriam as possibilidades de emancipação atualmente? E quais seriam, também, as saídas para uma esquerda crítica na "era das expectativas decrescentes"? E será que a gente, também, na nossa gramática política de esquerda, deveria repensar concepções como Reforma, Revolução...?

Paulo Arantes: Bom, vamos ponto por ponto. Vamos recordar, senão eu não vou lembrar de tudo. Vocês fizeram umas dez perguntas aí, comprimidinhas... Então, o primeiro ponto: Junho e...?

Humanidades em DiÁlogo: E as manifestações subsequentes contra o PT... 
Paulo Arantes: Isso... Se Junho é o epicentro desse terremoto que jogou a esquerda, petismo, lulismo na lata do lixo? Foi isso que aconteceu de fato, né? Bom, eu acho que precipitou. Digamos: Junho é o primeiro sintoma de que alguma coisa tinha acabado, se esgotado. Não quero fazer nenhum tipo de correlação - processo econômico com manifestação política, cultural, social... Não é assim tão simples, mas Junho acho que surpreendeu todo mundo. Eu digo isso lá no texto; os meus jovens amigos do MPL [Movimento Passe Livre] não me convencem de que aquilo estava planejado para acontecer daquela maneira. Ninguém nesse país imaginava que uma campanha para revogação de um aumento de tarifa colocasse milhões de pessoas na rua durante semanas a fio. Isso não estava escrito em lugar nenhum. Então, essa coisa surpreendente tem... Nenhuma teoria, retrospectivamente, justificou isso que eu tenha notado até agora. Portanto, alguma coisa rachou lá embaixo. A gente não sabe exatamente o que é. Chamar isso de "insurgência", eu uso um pouco, mas abusando... É uma maneira de falar para, digamos, contrastar. O Lula tinha saído com $80 \%$ de aprovação depois de oito anos. Não era pelo carisma, era porque, de fato, havia uma espécie de sentimento de que as coisas funcionavam, por mais extravagantes que possam ter sido os motivos de aprovação, que são dos mais banais até os mais estereotipados. De qualquer maneira, a sensação é de que havia uma espécie de unanimidade, de pacificação. A esquerda propriamente dita era um gueto, estava falando sozinha, mas sabia que havia um mal-estar no subterrâneo da sociedade. $O$ fato de o Brasil estar se encaixando em um contexto internacional específico fazia com que aumentasse esse sofrimento social por causa dessa mobilização pelo trabalho precário. Então, nós desconfiávamos que alguma coisa fermentava lá embaixo, mas nós falávamos para as paredes.

O MPL, no caso, vai dizer: "mas nós não falávamos para as paredes, nós sabíamos que havia um mal-estar profundo no transporte coletivo, na circulação das pessoas em uma cidade como São Paulo, e que em certo momento isso ia explodir". É... Sabiam e não sabiam. Enfim, sabiam, mas não imaginavam que tinha essas proporções. Então, a sensação era de que a pacificação, que vem desde a transição da ditadura para os dias de hoje, tinha se intensificado com o lulismo, isto é, o campo popular não era tão feio quanto parecia e, portanto, podia perfeitamente ser integrado no establishment brasileiro de poder que nenhum terremoto aconteceria. Isso o Lula tinha garantido. Tinha coincidido com a explosão de commodities. A estratégia de consumo, crédito e commodities tinha funcionado bem. Com uma aprovação de $80 \%$, ninguém mete a mão nisso! Ninguém desestabiliza, nem que quisesse.

Para culminar nesse estado de apoteose mental, havia uma espécie de consenso na esquerda da qual eu descendo, a assim chamada tradição crítica 
brasileira, os teóricos da formação de uma sociedade nacional do trabalho, que se sentiram, assim, justificados. Aquilo que fora interrompido brutalmente em ig64 teria, afinal, sido retomado no momento em que o campo popular se estruturou, se exprimiu politicamente e foi administrado por um líder carismático, que aplicou sabiamente as políticas recomendadas por vários organismos multilaterais, a começar pelo Banco Mundial - Bolsa Família não é invenção local, é programa do Banco Mundial.

Como é que você governa uma população que está sendo descartada pela autonomização total do processo econômico? Isso aqui gerou um experimento social interessante, porque o capitalismo hoje é para poucos. Essa massa sobrante foi muito bem administrada ao longo dos oito ou, digamos, quase doze anos do lulismo. Então, estava todo mundo satisfeito, de banqueiro a empreiteira. O resto é picuinha partidária de gente que ficou longe da rapadura todos esses anos.

Até então, pobre votava na oligarquia. O Lula rompeu com isso. Foi o primeiro desde Getúlio. Ao se romper com isso, ganha-se eleição. A menos que se acabe com essa história de eleição. Já deu para o gasto. Encerramos essa história de eleição e pronto. Eles achavam e continuam achando - e o PT também achava isso - que a crise era conjuntural. Você faz um ajuste - eles iam fazer um ajuste, os meus amigos do PT sabiam que eles iam fazer isso, não houve estelionato - e resolve. Houve estelionato porque enganaram a população. Nesse sentido, sim. Mas todo mundo sabia que eles iam aplicar esse troço que fizeram depois, que os tucanos iam fazer. Que havia cacife suficiente para se fazer um regime de austeridade "à la grega" se fosse o caso, e que depois se retomava porque o país não é pobre. Retomava-se e, portanto, ganhava-se a eleição em 2018. Isso era uma ideia insuportável. Eles acreditavam que isso ia acontecer, então interromperam nesse momento. A essência do golpe é praticamente essa.

Quer dizer, eles acreditavam nessa ficção de que você retoma mais adiante e que, portanto, essa crise é passageira, temporária, e que mais adiante você volta ao patamar anterior. Pura ilusão. A coisa se desintegrou um pouco mais. Está barbarizando mais ainda. Esse mal-estar lá de baixo começa a aflorar em Junho de 20I3, e o preço que está sendo pago é muito alto. Há uma enganação que faz com que as pessoas se mobilizem na rua por reivindicações básicas, por serviço público. Ela tem ares de insurgência, porém, na verdade, é a reivindicação mais conformista possível. Saúde, escola, transporte e assim por diante. Não tem nada de revolução. Isso não é revolução, não é insurgência, não é subversão. Mas é tal que é insuportável. Então, Junho precipita isso e coincide com a crise econômica propriamente dita. 
Portanto, mesmo com o PIB crescente, isso mostra essa sensação de desamparo, abandono, desleixo e, sobretudo, de decepção. Uma das boas teorias desse tipo de reversão de expectativas é a seguinte: a pacificação lulista, o que é? É dizer também que a solução é a do mercado. Só que a novidade do lulismo é que nós vamos colocar vocês, que estão fora, dentro. Não só com programas ditos assistenciais, mas com crédito consignado, valorização do salário mínimo e assim por diante. Lula sempre disse isso: nunca enganou ninguém. Só a nós, a esquerda, que queríamos nos enganar. Vão lá nos documentos de fundação do PT. Ele diz assim: "eu quero, pura e simplesmente, como líder sindical, que a classe trabalhadora do Brasil tenha uma presença política equivalente, ou compatível, ou que corresponda à sua presença social e econômica, portanto, ter um partido que participe do poder. $\mathrm{O}$ que foi interditado na ditadura. A ditadura criou o nosso poder social e econômico, criou a região proletária do $\mathrm{ABC}$. Mas nós ainda não dispomos do correspondente político dessa nova força social. Eu simplesmente estou aqui para anunciar que nada mais se fará no país sem que se ouça a voz politicamente organizada da classe trabalhadora. Não é revolução, não é socialismo, não é nada disso. No máximo nem poderia ser um Estado Social, um 'Welfare' europeu, porque isso também já está fora de cogitação em qualquer lugar do mundo". E ele fez isso e, ao cumprir isso, o recado foi entendido. Daí a adesão, o famoso realinhamento eleitoral. O que se entendeu do outro lado? O homem está cumprindo o prometido, está multiplicando os canais de acesso a esses bens públicos através do consumo. O Estado está quebrado, mesmo, então não vai mais haver um Estado Social europeu. Não tem nem na Europa, imagine aqui.

De modo que a mensagem foi esta: o Estado não pode mais ser um provedor universal, não há mais condições. Mas o mercado pode, desde que você chegue a ele, e você chegará através do emprego, mesmo que seja uma ocupação muito reles, lá embaixo, mas também através de uma rede de transferências monetárias diretas etc. Tudo está privatizado, mas vocês terão acesso a esses bens privatizados, que eram antigamente públicos. Acontece que isso não se realiza mais. Essa mágica é uma mágica besta, mas funcionou como um milagre social, porque o Brasil já estava partido. Essa saída de emergência funcionou como um experimento social provisório porque as pessoas se sentiram mais ou menos contempladas, quer dizer, "estão olhando por nós agora, temos um lugar ao sol" - mais ou menos isso. Só que isso é "Aquiles e a tartaruga", pois não alcança nunca o plano de saúde, o transporte está sempre um pouco além, eles não conseguem comprar como a classe média propriamente dita compra. Por isso, quando a meninada saiu para fazer pesquisas nas manifestações, até mesmo coxinhas pré-impeachment davam $80,90 \%$ de "nós queremos serviços públicos, universais, gratuitos e fornecidos pelo Estado. Como não há, nós recorremos ao 
mercado, mas nós gostaríamos de não ter que recorrer ao mercado, porque não dá, não estamos aguentando, também estamos morrendo na fila do hospital".

Veja, esse sonho que começou a se romper em Junho é um sonho rebaixado, ao contrário do sonho do Getúlio Vargas. A comparação com o Vargas, neste momento, é pertinente. O que o Vargas fez? O mundo do trabalho será o mundo da cidadania política também. Como é que o Vargas fez isso? O Vargas fez um milagre perverso: ele fez com que a população se tornasse fiel e leal a um Estado que sempre matou no Brasil. Desde o Império, o Estado mata, extermina, quando não recruta para o Exército à força. A relação dele com a população é antagônica. O Getúlio virou isso. Um Estado paternal vai oferecer para as camadas que estão lá embaixo o passaporte para alguns direitos, que é a Carteira de Trabalho. Então, se você entra numa profissão regulada e tem a sua carteira de trabalho, você terá acesso a alguns direitos, como proteção social, aposentadoria, pensão.

Porém, isso foi feito somente para algumas categorias de trabalhadores urbanos. Oras, o que é que o Getúlio fez? Ele fez o seguinte: até então, o lado mais brutal da vida social brasileira era um embate entre proprietários e não proprietários. E, no Brasil, se você toca na propriedade - não só no Brasil - o homem vira bicho. Daí a brutalidade da luta de classes no país. A possibilidade de você escapar dessa carnificina ou desse rebaixamento social sem redenção é a de você se assalariar. Então, o assalariamento capitalista propriamente dito passa a ser uma tábua de salvação e essa tábua de salvação está registrada na Carteira de Trabalho. Ali você tem a consolidação das leis do trabalho, a CLT, essa miragem na memória popular. É a única maneira que você tem, não sendo proprietário, de não ser automaticamente pisoteado.

Vem, assim, da Era Vargas essa utopia de redenção social pela carteira assinada. O Getúlio era isso e, precisamente com essa miragem, desarmava toda a oposição da esquerda socialista, anticapitalista, cujo discurso ia na contramão da subordinação pelo assalariamento, entendido como alienação e exploração. Vargas martelava o extremo oposto: "não, o assalariamento é a redenção e, portanto, a meta é a sociedade dos trabalhadores legalizados".

Quando o Lula chegou, quando o petismo chegou, essa sociedade do trabalho, em termos estruturais no capitalismo contemporâneo, já tinha ido para o brejo. Não há milagre que faça a reconstituição ou a constituição de uma sociedade do trabalho no Brasil, ou uma sociedade salarial tal como existe, ou existiu, na Europa no pós-guerra. Então, intuitivamente, doutrinas à parte, sabia-se que isso não era mais possível, não tinha mais como fazer isso.

O que é que se fez então? Você "inclui", sabe-se lá onde, pelo consumo, pelo crédito, quando o dinheiro das commodities começou a chover na horta, enquanto o Brasil se desindustrializava. Pouco importava. O que importava 
é que estava chovendo dinheiro. Então, você podia multiplicar empregos de dois salários mínimos no máximo, alavancando as pessoas numa espécie de falso pleno emprego. Com todo mundo empregado, ia se chegar ao mundo dos direitos anunciados pela Constituição de 88 .

Portanto, em relação ao Vargas, é um rebaixamento geral, mas é um rebaixamento não por perversidade ou por miopia política e ideológica. É por saber que essa é a única via de você segurar, por mais uma geração, no máximo, a desagregação social galopante que vinha desde a crise da dívida, da década de oitenta. Essa engenharia os petistas fizeram. Não era isso que eles pensavam lá atrás. No máximo, estabelecer-se de vez entre os donos do poder como parceiros confiáveis, até na alternância eleitoral as usual. Até hoje não se sabe, é um mistério, por que a burguesia brasileira, para falar em termos clássicos, recusou a internacionalização do capitalismo brasileiro que o lulismo estava lhe oferecendo e ofereceu com algum sucesso. A expansão dos negócios brasileiros, as multinacionais brasileiras pela América Latina, pela África, estava indo bem. Num certo momento, quando o cobertor começou a encurtar, teriam que fazer uma reforma e retomar mais adiante. Recusaram! Até agora ninguém explicou, ninguém estava perdendo nada...

Mas, enfim, Junho é isso. Junho é simplesmente a implosão desse sonho amesquinhado. O horizonte do desejo (Wanderley Guilherme) tinha sido rebaixado a este ponto: o horizonte de um crediário. Quando o Lula disse "eu quero que o Brasil seja uma imensa Casas Bahia", ele estava pensando exatamente isso. Do ponto de vista sociológico, é impecável. Por que a classe dominante recusou a possibilidade de transformar o país numa imensa Casas Bahia? Porque estava funcionando! As pessoas estavam ali, mais ou menos acomodadas, sofrendo, mas estavam indo. E era uma engenharia social complexa, bem feita, bem articulada e bem gerida.

Os que estão aí não têm condições, nem os que virão depois terão mais condições. Porque aí detonou geral. Agora é gangue mesmo, administração direta das empresas. Não tem mais intermediário. O que já era capitalismo de cupinchas entornou de vez. É o inominável que se está vendo agora. As privatizações selvagens em curso são só isso mesmo: selvageria, predação direta.

Dizer que, veja só, o que era o discurso dito da esquerda no sentido convencional, histórico ou biográfico, que isso era um projeto emancipatório... Tenha paciência! Dizer que o Bolsa Família é emancipatório!? Ele é uma outra coisa que nós não sabemos definir ainda. Tem gente estudando, tentando definir. O que significa, para o universo de pobrezas e de carências terríveis, respirar? Respirar com uns trocados, sair do sufoco? Porque o dinheiro faz com que você quebre por um momento a sensação de penúria e de você estar sendo sufocado. 
Isso provoca uma sensação de alívio social muito grande. Não tem nada a ver com a emancipação. É alguém que entra numa emergência, num pronto-socorro, arrebentado e mal atendido. Não tem nada que pague isso. $\mathrm{O}$ equivalente social disso é consagração política mesmo. Passar a dor imediata é o que importa. $\mathrm{O}$ que conta é isso mesmo e estava funcionando, mas isso é uma saída de emergência, não é projeto de nada. Esse que é o problema. Não tendo mais horizonte, o mero reconhecimento social pelo dinheiro pode explodir a qualquer momento.

Então, a emancipação, com aspas ou sem aspas, significa apenas isto: não queremos mais ser governados dessa maneira! É isso. Como seremos? Ninguém sabe. O que é inacreditável e assustador, do meu ponto de vista pelo menos, é que a casta dominante, junto com esses novos sócios, que eles haviam tolerado nos últimos quinze anos, deu um tiro no pé! É claro que tinha que ter feito um remanejamento. Era necessário porque, novamente, as coisas baixaram no plano mundial. Eles iam fazer isso. Sem saber o que estavam fazendo, os golpistas deram um cavalo de pau e detonaram o negócio.

Isso aqui não vai durar - chegar a 2018 é apenas uma data de crediário. Você imagina o que vai estar isso aqui daqui um ano. Tem mais de mil escolas ocupadas. Você está sublevando secundaristas, então, aonde nós chegamos?! Para nós é ótimo a moçada estar fazendo isso, levantando um pouco a cabeça: não é assim, ponto! Mas também não é revolução. Quando eu falo "a escola é nossa", alto lá! A escola é nossa em que sentido? "As fábricas de cultura que foram paralisadas em São Paulo são nossas"! Nossas aqui do pedaço, da quebrada. Faz uma risca no chão, daqui não passa! Então, nós queremos voltar ao que era antes. Nosso é nosso! Então, "a escola é nossa" é ambíguo. Pouco importa, tudo é ambíguo, mas, enfim, já é alguma coisa. Vamos pensar que é uma perspectiva, digamos: é promissor, é alentador, mas é um fim de linha. Mas está assim no mundo inteiro. O fim de linha não é só nosso, não. Tem sublevação secundarista no Chile, na França e por aí vai. Na Inglaterra, na Itália, está todo o mundo nisso também. Então você vê: a distinção entre reforma e revolução foi para o brejo. Você tem motins! Na verdade, são meninos e meninas de quatorze, quinze e dezesseis anos. Estão amotinados. É como rebelião em cadeia, mutatis mutandis. Por isso que vai lá a polícia, vão lá os secretários e algemam, porque só sabem fazer isso: gestão armada das turbulências sociais.

Mas, claro, tem democracia interna, tem uma autonomia funcionando ali durante algumas horas, alguns dias ou semanas. Funciona alguma coisa que parece autonomia e, portanto, liberdade e democracia. A gente sabe que ela é provisória, que vai ser sufocada e que tem fôlego curto, porque é o "nosso" sendo só nosso, não envolvendo mais ninguém. Acabou. Mas não é por causa disso que você não vai fazer. Tem que lutar. 